\title{
Temporal bone dissection guide: second edition
}

\section{Didier Martin}

To cite this article: Didier Martin (2017): Temporal bone dissection guide: second edition, Acta Chirurgica Belgica, DOI: 10.1080/00015458.2016.1258807

To link to this article: http://dx.doi.org/10.1080/00015458.2016.1258807

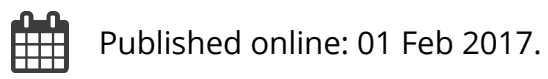

[S Submit your article to this journal

\section{Џll Article views: 3}

Q View related articles ๘

View Crossmark data ¿ 


\section{BOOK REVIEW}

Temporal bone dissection guide: second edition, edited by H. W. Francis and J. K. Niparko, New York, Thieme Publishers, 2016, 96 pages, ISBN: 978-1-62623-113-9

The temporal bone is an anatomical structure of an extraordinary complexity. The minuscule scale of its critical neurovascular structures combined with their convoluted three-dimensional relationships make microsurgery of this region one of the most technically demanding of all operative endeavours. Tumours and erosive lesions create additional anatomical barriers that make effective access and resection of the pathological areas difficult. At the same time, the surgical skills required to navigate this anatomy are indispensable to the management of ear disease and associated disability, and provide alternative approaches with less morbidity to intracranial pathology.

This book presents technical and strategic considerations for safe and effective temporal bone surgery. The renowned authors share their collective wisdom and pearls gleaned from years of treating patients with temporal bone disease and teaching these methodologies to medical students, residents, and fellows. Procedural details are presented throughout 10 detailed chapters, accompanied by beautiful sequential illustrations and videos. This second edition of this guide provides a step-by-step approach to learning the anatomy and principal procedures of temporal bone dissection starting with mastoidectomy and including approaches to the internal auditory canal and jugular foramen.

The key highlights of the book are videos of cadaveric or surgical dissections and meticulous drawings of progressive dissections. In this second edition, a new chapter on middle ear endoscopy has been added and gives details key anatomical features and technical manoeuvres integral to this approach. Other new chapters on infratemporal surgical dissection and the intraoperative management of complications are also presented. An expanded coverage of the middle fossa approach to the internal auditory canal and methods of assessing competencies when training novice surgeons in temporal bone dissection.

This book is a must-have tool that will enable residents and novice surgeons to translate laboratory skills to the operating room and perform safe, efficacious and efficient dissection of the temporal bone. It is the quintessential learning guide for residents in otolaryngology-head and neck surgery and skull base surgery, as well as an excellent teaching and assessment tool for faculty.

Didier Martin

University Hospital of Liège

$\mathrm{CHU}$ de Liège

Sart Tilman B35

4000 Liège, Belgium

didier.martin@chu.ulg.ac.be

(C) 2017 The Royal Belgian Society for Surgery http://dx.doi.org/10.1080/00015458.2016.1258807 